\title{
Genetic Polymorphism in Brazilian Microcystis spp. (Cyanobacteria) Toxic and Non-Toxic Through RFLP-PCR of the $\operatorname{cpcBA}$-IGS
}

\author{
Maria do Carmo Bittencourt-Oliveira ${ }^{1 *}$, Maristela Casé Costa Cunha ${ }^{2}$ and Ariadne do \\ Nascimento Moura ${ }^{2}$ \\ ${ }^{1}$ Departamento de Ciências Biológicas; Escola Superior de Agricultura Luiz de Queiroz; Universidade de São \\ Paulo; Av. Pádua Dias, 11; 13418-900; Piracicaba - SP - Brasil. ${ }^{2}$ Departamento de Biologia; Universidade \\ Federal Rural de Pernambuco; Recife - PE - Brasil
}

\begin{abstract}
The escalating occurrence of cyanobacterial toxic blooms demands a better understanding of genetic variability as an auxiliary expedient in species identification, collaborating with the monitoring of water destined to public supply. This study aimed at the unraveling of genetic polymorphism in the toxic and nontoxic strains of Microcystis (Cyanobacteria) species, isolated from diverse Brazilian localities through the RFLP-PCR technique applied to the c-phycocyanin encoding operon and its intergenic spacer (cpcBA-IGS). Eighteen strains belonging to M. aeruginosa, M. panniformis, M. protocystis and M. wesenbergii, plus two other unidentified strains, were analyzed by means of the morphological and molecular data. The molecular data constituted three groups with low similarity values unrelated to the geographical origin, toxicity or morphospecies. A high genetic variability among the studied populations was unveiled by the results. Brazilian populations of Microcystis spp. displayed high genetic diversity when compared to those from Australia, Japan, United States and Europe. This ample genetic diversity could be observed through the diverse eletrophoretic profiles obtained among the strains from a single species. The presence of toxic and non-toxic strains was observed in the same species, as M. aeruginosa.
\end{abstract}

Key words: Cyanobacteria, $c p c \mathrm{BA}-\mathrm{IGS}$, genetic polymorphism, microcystin, Microcystis, RFLP

\section{INTRODUCTION}

The cyanobacterial genus Microcystis (Kützing) ex Lemmermann (Cyanobacteria) 1907 has been associated with the toxic water blooms in many places around the world (Codd et al., 1999; Skulberg et al., 1994; Vasconcelos et al., 1996). The most serious and worldwide known case involving the humans took place in Brazil, as 1996 (Jochimsen et al., 1998; Carmichael et al., 2001).
The increasing occurrence of toxic cyanobacterial blooms asks for a better understanding of genetic polymorphism as auxiliary tool helping species identification, as well as collaborating in the monitoring of the water for the public supply, once the identification of these organisms is established by widely variable morphological characteristics (Bittencourt-Oliveira and Moura, 2007; Bittencourt-Oliveira et al., 2007).

\footnotetext{
* Author for correspondence: mbitt@esalq.usp.br
} 
The c-phycocyanin genes $(c p c \mathrm{~B}$ and $c p c \mathrm{~A})$ and the intervening intergenic spacer ( $c p c$ BA-IGS) show ariations in their sequences which are capable of differentiating genotypes below the generic level because they are highly polymorphic. Besides, they are relatively large-sized in comparison with other genes encoding for the photosynthetic pigments ( 700-800 bp), belong to all cyanobacteria and are restricted to these organisms when in freshwater ecosystems (Neilan et al., 1995; Bolch et al., 1996, 1999, BittencourtOliveira et al., 2001).

This study aimed to understand the genetic polymorphism by means of the RFLP-PCR (Restriction Fragment Length Polymorphic Polymerase Chain Reaction) technique applied to the intergenic spacer for the c-phycocyanin genes and flanking regions ( $c p c \mathrm{BA}-\mathrm{IGS}$ ) in the toxic and non-toxic strains of Microcystis species, isolated from the diverse places in the Brazilian territory.

\section{MATERIAL AND METHODS}

The water samples were collected from many ecosystems in the Brazilian territory, which were used mainly for the water supply and recreation (Table 1).

The eighteen clonal and non-axenic strains of Microcystis spp. were used in this study (Table 1). One individual colony was removed by micromanipulation technique with Pasteur pipettes. Each isolated colony was washed, by transferring it through several consecutive drops of water until all other microorganisms were removed, and subsequently transferred to glass tubes containing $10 \mathrm{ml}$ of BG-11 medium (Rippka et al., 1979) using $\mathrm{FeCl}_{3} \cdot 6 \mathrm{H}_{2} \mathrm{O}$ instead of ferric ammonium citrate. After a few weeks, the colonies became unicelullar and they were transferred to Petri dishes containing bacteriological agar at $1 \%$ (w/v) and BG-11 medium (modified). After growing on agar, an isolate was transferred to a tube containing liquid medium. The cultures were examined microscopically to ensure that there were no contaminating cyanobacteria. All the strains were maintained at $21 \pm 1^{\circ} \mathrm{C}, 30 \mu \mathrm{mol}$ photons $\mathrm{m}^{-2} \cdot \mathrm{s}^{-1}$ (photometer Li-Cor mod. 250), under a 14:10 h L:D (light:dark) photoperiod at the Brazilian Cyanobacteria Collection of the University of São Paulo, Brazil-BCCUSP.
Field colonies were identified at specific level when this was possible, through the wild phenotypes preserved with formalin $10 \%$ (1:10) based on the morphological characteristics used for Microcystis species (Komárek and Anagnostidis, 1999; Komárek and Komarková, 2002). One drop of the diluted nankeen was used on the lamina to make the mucilage evident. During the cultivation in the laboratory, some strains showed morphological variation and became unicellular. The means of cell diameter were calculated $(n=50)$ for each strain in midlogarithmic phase. The averages of cell diameter and standard deviation were statistically analyzed using SAS software (version 8.0). Photomicrographs of the colonies were taken with a Leica DMLS (Leica Microsystems, Wetzlar, Germany) microscope equipped with a video camera system (Image Pro Plus version 4.0, Media Cybernetics, Silver Spring, MD, USA).

The DNA for PCR was prepared using the InstaGene $^{\mathrm{TM}}$ Matrix (BioRad Laboratories, Hercules, CA, USA), by the method of Neilan et al. (1995) modified as described by Bolch et al. (1996). PCR amplifications were performed using the modified protocols and $c p c$ BA-IGS oligonucleotide primers as described by Bolch et al. (1996). (PC $3-\mathrm{F}:$ 5'GGCTGCTTGTTTACGCGACA-3'; PC $\alpha-\mathrm{R}: 5^{\prime}$ CCAGTACCACCAGCAACTAA-3'.

Amplifications were carried out in $25 \mu \mathrm{L}$ using Ready-To-Go PCR Beads kit (Amersham Pharmacia Biotech, Piscataway, NJ, USA), with 5 pmol of each primer and approximately $1.5 \mathrm{ng}$ genomic DNA. The following cycling parameters were used: $92^{\circ} \mathrm{C}$ for $2 \mathrm{~min}$, followed by 40 cycles of $92^{\circ} \mathrm{C}$ for $40 \mathrm{~s} ; 55^{\circ} \mathrm{C}$ for $50 \mathrm{~s}$, and $72^{\circ} \mathrm{C}$ for 2 min, followed by a final extension at $72^{\circ} \mathrm{C}$ for 8 min in a GeneAmp 2400 thermocycler (PerkinElmer, Foster City, CA, USA).

The restriction digestion amplification products were checked for successful amplification. Unreacted PCR components, primers and buffers were removed by purification through QIAQuick columns (Qiagen, Valencia, CA, USA) according to the manufacturer's instructions. The DNA concentrations were estimated directly from ethidium bromide fluorescence in agarose gel images against standard quantities of DNA (Low DNA mass, Invitrogen, Carlsbad, CA, USA). 
Table 1 - Strains used in this study: morphospecies, diameters cell, restriction enzymes types and microcystins production. GA: Garças lagoon, São Paulo, São Paulo State (23 39'S, 46 37’ W); CT: Cantareira reservoir, Mairiporã, São Paulo State $\left(23^{\circ} 19^{\prime} 12^{\prime \prime}\right.$, $\left.46^{\circ} 35^{\prime} 18^{\prime \prime W}\right)$. SG: Salto Grande reservoir, Americana, São Paulo State

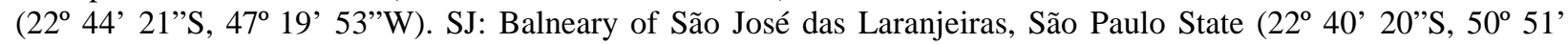

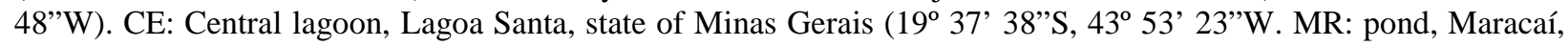
São Paulo State ( $22^{\circ} 36.34^{\prime}$ 6”S, 50 38.48' 6”W). JP: Jacarepaguá lagoon, Rio de Janeiro, state of Rio de Janeiro

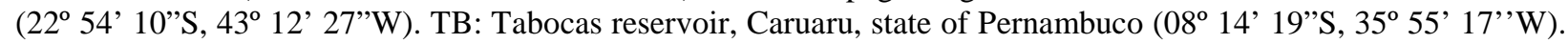
MCY: microcystins presence (+) and absent (-) using ELISA. SD: standard deviation. BCCUSP: Brazilian Cyanobacteria Collection of University of São Paulo. IBCCF/UFRJ: Instituto de Biofísica Carlos Chagas Filho/Universidade Federal do Rio de Janeiro (NPLJ-4, NPLJ-47, NPJB-1, NPCD-1and NPLS-1). ND: not determined.

\begin{tabular}{|c|c|c|c|c|c|c|c|c|c|c|c|c|}
\hline \multirow[t]{2}{*}{ Strain $^{\mathrm{a}}$} & \multirow{2}{*}{$\begin{array}{c}\text { Local } \\
\text { Sample } \\
\end{array}$} & \multirow[t]{2}{*}{ Date } & \multirow[t]{2}{*}{ Mean $(\mu \mathrm{m})$} & \multirow[t]{2}{*}{ Min-Max. $(\mu \mathrm{m})$} & \multirow[t]{2}{*}{ SD } & \multicolumn{6}{|c|}{ Restriction Enzymes Types ${ }^{b}$} & \multirow[t]{2}{*}{ MCY } \\
\hline & & & & & & Acc & Hae & Hha & Msp & Rsa & Sau & \\
\hline \multicolumn{13}{|c|}{ M. panniformis Komárek et al. } \\
\hline BCCUSP03 & GA & Dec 1996 & 4.39 & $3.96-4.95$ & 0.45 & $\mathrm{Ac}_{1}$ & $\mathrm{Ha}_{3}$ & $\mathrm{Hh}_{2}$ & $\mathrm{Ms}_{3}$ & $\mathrm{Rs}_{1}$ & $\mathrm{Sa}_{2}$ & - \\
\hline BCCUSP30 & GA & Nov 1996 & 2.72 & $1.98-2.97$ & 0.42 & $\mathrm{Ac}_{1}$ & $\mathrm{Ha}_{4}$ & $\mathrm{Hh}_{4}$ & $\mathrm{Ms}_{5}$ & $\mathrm{Rs}_{2}$ & $\mathrm{Sa}_{1}$ & - \\
\hline BCCUSP158 & GA & Dec 1996 & 4.85 & $3.96-4.95$ & 0.31 & $\mathrm{Ac}_{1}$ & $\mathrm{Ha}_{3}$ & $\mathrm{Hh}_{2}$ & $\mathrm{Ms}_{4}$ & $\mathrm{Rs}_{1}$ & $\mathrm{Sa}_{2}$ & - \\
\hline BCCUSP199 & GA & Dec 1996 & 4.55 & $3.96-4.95$ & 0.46 & $\mathrm{Ac}_{1}$ & $\mathrm{Ha}_{3}$ & $\mathrm{Hh}_{2}$ & $\mathrm{Ms}_{3}$ & $\mathrm{Rs}_{1}$ & $\mathrm{Sa}_{2}$ & - \\
\hline BCCUSP200 & SG & Aug 1996 & 3.76 & 2.97- & 0.67 & $\mathrm{Ac}_{1}$ & $\mathrm{Ha}_{1}$ & $\mathrm{Hh}_{3}$ & $\mathrm{Ms}_{1}$ & $\mathrm{Rs}_{1}$ & $\mathrm{Sa}_{1}$ & $+^{\mathrm{c}}$ \\
\hline \multicolumn{13}{|c|}{ M. wesenbergii Komárek (Komárek) in Kondrateva } \\
\hline BCCUSP11 & MR & Feb 1998 & 5.47 & 3.96 & 0.9 & $\mathrm{Ac}_{1}$ & $\mathrm{Ha}_{2}$ & $\mathrm{Hh}_{7}$ & $\mathrm{Ms}_{5}$ & $\mathrm{Rs}_{3}$ & $\mathrm{Sa}_{3}$ & - \\
\hline \multicolumn{13}{|c|}{ M. aeruginosa (Kützing) Kützing } \\
\hline NPJB-1 ${ }^{\mathrm{d}, \mathrm{e}}$ & GA & 1990 & 4.74 & $3.96-5.9$ & 0.62 & $\mathrm{Ac}_{1}$ & $\mathrm{Ha}_{3}$ & $\mathrm{Hh}_{1}$ & $\mathrm{Ms}_{2}$ & $\mathrm{Rs}_{1}$ & $\mathrm{Sa}_{1}$ & + \\
\hline NPLJ-47 ${ }^{\mathrm{d}, \mathrm{f}}$ & JP & 1996 & 4.75 & $3.96-4.95$ & 0.34 & $\mathrm{Ac}_{1}$ & $\mathrm{Ha}_{5}$ & $\mathrm{Hh}_{6}$ & $\mathrm{Ms}_{1}$ & $\mathrm{Rs}_{1}$ & $\mathrm{Sa}_{1}$ & + \\
\hline NPCD- $1^{\mathrm{d}, \mathrm{f}}$ & JP & 1992 & 4.25 & $3.96-4.95$ & 0.41 & $\mathrm{Ac}_{2}$ & $\mathrm{Ha}_{5}$ & $\mathrm{Hh}_{3}$ & $\mathrm{Ms}_{8}$ & $\mathrm{Rs}_{1}$ & $\mathrm{Sa}_{1}$ & - \\
\hline NPLJ-4 ${ }^{\mathrm{d}, \mathrm{g}}$ & $\mathrm{JP}$ & 1995 & 4.05 & $3.96-4.95$ & 0.31 & $\mathrm{Ac}_{1}$ & $\mathrm{Ha}_{5}$ & $\mathrm{Hh}_{6}$ & $\mathrm{Ms}_{1}$ & $\mathrm{Rs}_{1}$ & $\mathrm{Sa}_{1}$ & + \\
\hline BCCUSP09 & GA & May 1996 & 2.62 & $1.98-2.97$ & 0.33 & $\mathrm{Ac}_{2}$ & $\mathrm{Ha}_{4}$ & $\mathrm{Hh}_{9}$ & $\mathrm{Ms}_{7}$ & $\mathrm{Rs}_{4}$ & $\mathrm{Sa}_{3}$ & - \\
\hline BCCUSP296 & $\mathrm{CT}$ & Mar 1997 & 3.56 & $2.97-4.95$ & 0.68 & $\mathrm{Ac}_{1}$ & $\mathrm{Ha}_{2}$ & $\mathrm{Hh}_{2}$ & $\mathrm{Ms}_{2}$ & $\mathrm{Rs}_{1}$ & $\mathrm{Sa}_{1}$ & - \\
\hline \multicolumn{13}{|c|}{ M. protocystis Crow } \\
\hline BCCUSP04 & SJ & Feb 1999 & 3.16 & 96 & 0.41 & $\mathrm{Ac}_{1}$ & $\mathrm{Ha}_{5}$ & $\mathrm{Hh}_{5}$ & $\mathrm{Ms}_{9}$ & $\mathrm{Rs}_{3}$ & $\mathrm{Sa}_{1}$ & - \\
\hline BCCUSP05 & SJ & Feb 1999 & 3.36 & 2.97-3.96 & 0.34 & $\mathrm{Ac}_{1}$ & $\mathrm{Ha}_{2}$ & $\mathrm{Hh}_{5}$ & $\mathrm{Ms}_{5}$ & $\mathrm{Rs}_{1}$ & $\mathrm{Sa}_{1}$ & - \\
\hline BCCUSP06 & TB & 1997 & 4.74 & $3.96-5.90$ & 0.62 & $\mathrm{Ac}_{1}$ & $\mathrm{Ha}_{5}$ & $\mathrm{Hh}_{1}$ & $\mathrm{Ms}_{1}$ & $\mathrm{Rs}_{1}$ & $\mathrm{Sa}_{1}$ & ND \\
\hline BCCUSP07 & $\mathrm{TB}$ & 1997 & 3.11 & $1.98-3.96$ & 0.62 & $\mathrm{Ac}_{1}$ & $\mathrm{Ha}_{2}$ & $\mathrm{Hh}_{8}$ & $\mathrm{Ms}_{6}$ & $\mathrm{Rs}_{1}$ & $\mathrm{Sa}_{3}$ & - \\
\hline \multicolumn{13}{|l|}{ Microcystis sp. } \\
\hline NPLS-1 ${ }^{\mathrm{d}}$ & $\mathrm{CE}$ & 1993 & 3.26 & $2.97-3.96$ & 0.47 & $\mathrm{Ac}_{1}$ & $\mathrm{Ha}_{2}$ & $\mathrm{Hh}_{5}$ & $\mathrm{Ms}_{5}$ & RsB & $\mathrm{Sa}_{1}$ & - \\
\hline BCCUSP08 & $\mathrm{TB}$ & Feb 1999 & 3.86 & $2.97-3.96$ & 0.31 & $\mathrm{Ac}_{1}$ & $\mathrm{Ha}_{1}$ & $\mathrm{Hh}_{1}$ & $\mathrm{Ms}_{1}$ & $\mathrm{Rs}_{1}$ & $\mathrm{Sa}_{1}$ & - \\
\hline
\end{tabular}

${ }^{\mathrm{a}}$ All strains were maintained at Brazilian Cyanobacteria Collection of University of São Paulo, Brazil - BCCUSP. ${ }^{\mathrm{b}}$ The different restriction types detected by each enzyme among 18 analyzed strains are designated by subscripted numbers. ${ }^{c}$ False positive. Strain non-toxic, verified after HPLC and by the presence of the $m c y B$ gene involved in microcystin biosynthesis (data not showed). ${ }^{\mathrm{d}}$ The strains were unicellular-like, thus, confirmation of morphospecies was unfeasible. Species identification according to: ${ }^{\mathrm{e}}$ Azevedo et al., 1994. ${ }^{\mathrm{f}}$ Odebrecht et al., 2002. ${ }^{\mathrm{g}}$ Soares et al., 2004.

The restriction endonucleases digestion was perforomed with $90 \mathrm{ng}$ of PCR product and $5 \mathrm{U}$ of restriction enzymes Alu II, Acc I, Hae III, Hha I, Msp I, Rsa I and Sau 3AI (Gibco BRL, Gran Island, NY, USA), according to the manufacturer's instructions, and for approximately $12 \mathrm{~h}$ at $37^{\circ} \mathrm{C}$. Amplification products were visualized through the horizontal slab gels on $1.5 \%$ ultrapure agarose (Amersham Pharmacia Biotech, Piscataway, NJ, USA) with ethidium bromide $\left(0.2 \mu \mathrm{g} \mathrm{mL}^{-1}\right)$, and run for $4 \mathrm{~h} 1 \mathrm{X}$ TBE running buffer $(\mathrm{pH} \mathrm{8.0,89}$ $\mathrm{mM}$ Tris, $89 \mathrm{mM}$ boric acid and $2 \mathrm{mM}$ EDTA) at constant voltage of $2.4 \mathrm{~V} \mathrm{~cm}^{-1}$ for $1.5 \mathrm{~h}$. The agarose gels were recorded using Kodak electrophoresis Documentation and Analysis System 290 (EDAS 290) (Kodak, Melville, NY, USA) associated with Kodak 1D Image Analysis Software.

The RFLP fragments generated from $c p c$ BA-IGS were handled as phenotypes. The strains were comparatively analyzed through the presence or absence of a digested fragment. The generated restriction fragments were assembled and converted into binary codes based on the criterion 
of data presence (1) and absence (0). Doubtful bands of low resolution were disregarded. The similarity matrix was calculated by the Jaccard coefficient using NTSYS software (version 2.1) and the UPGMA algorithm was used for the phenogram construction (Sneath and Sokal, 1973). Microcystin production of investigated strains was obtained via immunoassay using the ELISA with EnviroLogix ${ }^{\mathrm{TM}}$ Microcystins Quantitative Plate Kit Microcystin (Envirologix Inc., Maine, USA).

\section{RESULTS}

Eighteen strains were identified as belonging to the $M$. panniformis Komárek et al., M. protocystis Crow, M. aeruginosa (Kützing) Kützing and $M$. wesenbergii Komárek (Komárek) in Kondrateva species (Table 1). The strains NPLS-1 and BCCUSP08 were not identified to specific level because during the course of this study, they became unicellular.

Despite the fact that the NPLJ-4, NPLJ-47, NPCD1 and NPJB-1 strains were unicellular, they had been identified in previous studies as $M$. aeruginosa (Azevedo et al., 1994 to NPJB-1; Odebrecht et al., 2002 to NPLJ-47 and NPCD-1;
Soares et al., 2004 to NPLJ-4). The means, standard deviations and microcystin production are shown in Table 1.

M. protocystis and M. panniformis (Fig. 1) were the species frequently found in Brazilian water bodies (Komárek et al., 2002). M. protocystis strains showed the colonies with small morphological variability, sparsely and irregularly arranged cells, and ample and diffluent mucilaginous envelope (Fig. 1a-b). The observation of $M$. protocystis was already reported for the Tabocas reservoir (Komárek et al., 2001), Caruaru city, where several patients from a hemodialyses clinic died (Jochimsen et al., 1998; Carmichael et al., 2001). Although a few studies suggested that some populations exhibited high toxicity (Komárek et al., 2001; Komárek et al., 2002), in the present study, no strain revealed itself as a microcystin producer.

$M$. panniformis strains exhibited ample morphological variability (Fig. 1c-d) as described in Bittencourt-Oliveira, 2000; Komárek et al., 2002; Bittencourt-Oliveira et al., 2005, 2007. Overlapping of cell diameter in M. panniformis, protocystis and $M$. aeruginosa morphospecies was observed (Table 1).

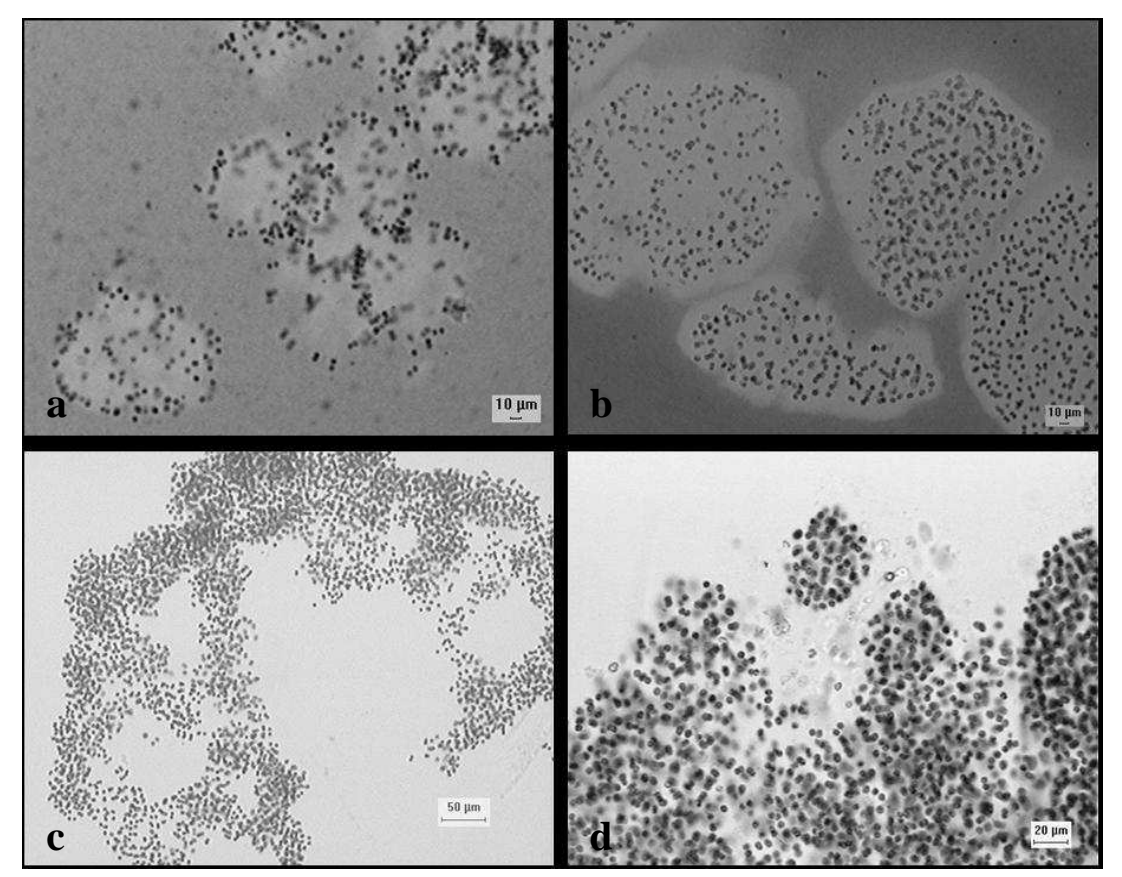

Figure 1 - The morphospecies M. protocystis and M. panniformis. (a) M. protocystis of environmental samples from Tabocas reservoir, Caruaru, PE and (b) Balneary of São José das Laranjeiras, SP. (c-d) M. panniformis isolated from (BCCUSP158) Garças lagoon, São Paulo, SP. 
The only $M$. wesenbergii analyzed strain presented a visible mucilaginous envelope, firm, refractive, forming a characteristic line around the colonies, with higher cellular diameters. Its life cycle phases have been presented by Otsuka et al. (2000) and Watanabe (1996).

Among all the analyzed morphspecies, only some $M$. aeruginosa strains revealed themselves as microcystin-producing (NPJB-1, from São Paulo state, NPLJ-4 and NPLJ-47 from Rio de Janeiro), which also showed the presence of toxic and nontoxic strains in the same species.

A single product with approximately $700 \mathrm{bp}$ was observed after DNA amplification, pointing, thus, to the presence of only one operon (data not shown). The electrophoretic profiles are shown in Fig. 2. The restriction enzyme Alu II did not digest the amplified fragment in any of the analyzed strains (data not shown). Acc I was capable in digesting only the fragments from two strains (BCCUSP09 and NPCD-1) (Fig. 2a) belonging to the same morphospecies, but from distinct localities. The remaining restriction enzymes provided different polymorphic profiles, Sau 3AI (Fig. 2b), Rsa I (Fig. 2c), Hae III (Fig. 2d) with 3, 4 and 5 profiles, respectively. On the other hand, the enzymes Hha I (Fig. 2e) and Msp I (Fig. 2f) exhibited nine profiles each.
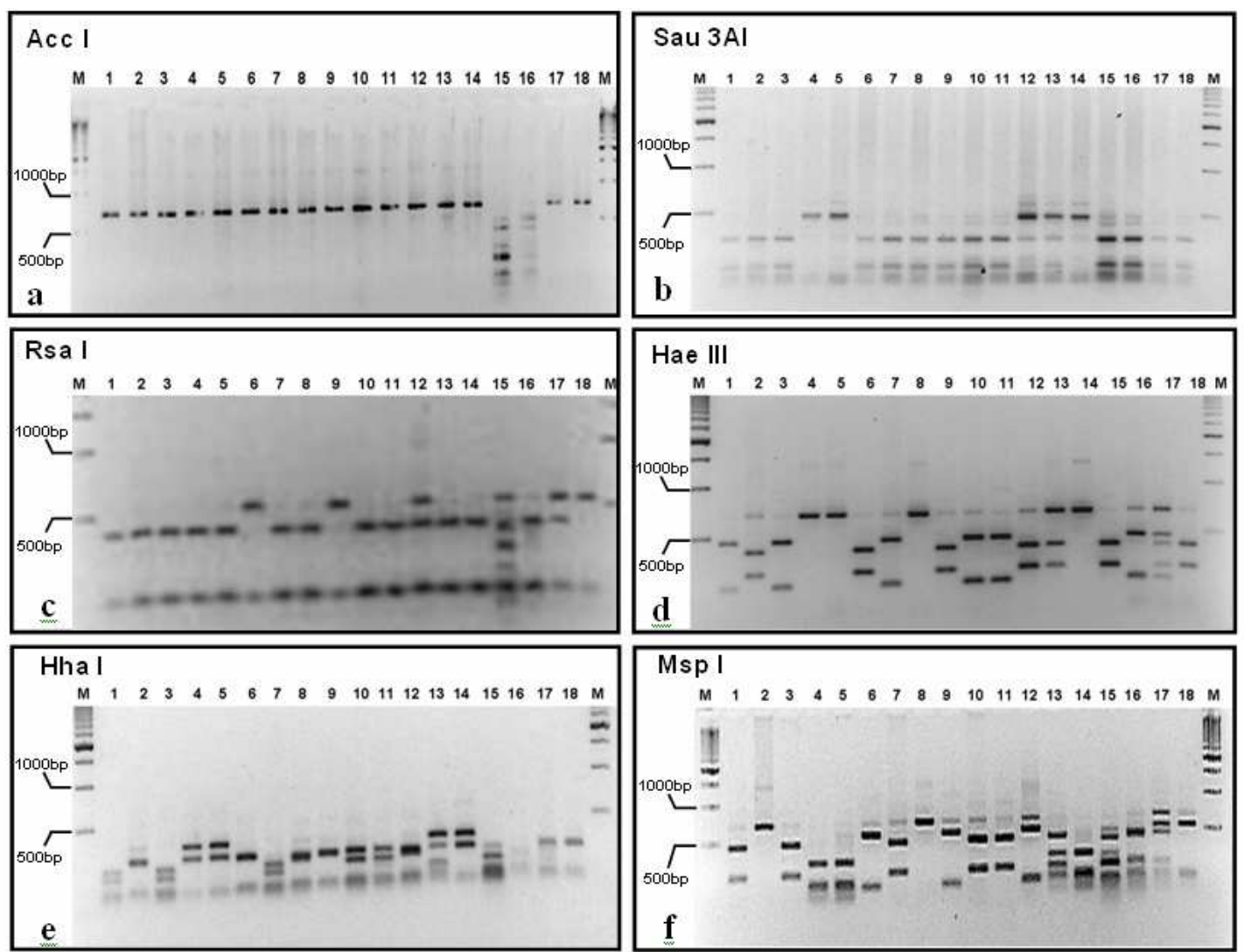

Figure 2 - Restriction digest of the $c p c$ BA-IGS PCR products of Microcystis spp. electrophoresed on a $1.5 \%$ agarose and stained with ethidium bromide. The profiles shown are (a) Acc I. (b) Sau 3AI. (c) Rsa I. (d) Hae III. (e) Hha I. (f) Msp I. M: DNA molecular weight standard 500 bp DNA Ladder (Gibco BRL, Gran Island, NY, USA) 1. BCCUSP08. 2. BCCUSP296. 3. BCCUSP200. 4. BCCUSP199. 5. BCCUSP158. 6. BCCUSP30. 7. BCCUSP06. 8. NPJB-1. 9. NPLS-1. 10. NPLJ-47. 11. NPLJ-4. 12. BCCUSP11. 13. BCCUSP07. 14. BCCUSP03. 15. BCCUSP09. 16. NPCD-1. 17. BCCUSP04. 18. BCCUSP05. 
Three clusters of the Brazilian Microcystis spp. were obtained with low similarity values (Fig. 3). Cluster I included two toxic strains (NPLJ-4 and NPLJ-47), four non-toxic strains (BCCUSP08, BCCUSP04, BCCUSP200 and NPCD-1), and one not analyzed strain (BCCUSP06). Cluster II included one microcystin-producing strain (NPJB1) and four non-toxic strains (BCCUSP296, BCCUSP30, BCCUSP05, NPLS-1 and
BCCUSP11). Cluster III included only non-toxic strains (BCCUSP158, BCCUSP199, BCCUSP03, BCCUSP07). Nevertheless, the strains were not grouped according to their geographical origin, water body, morphospecies, toxicity, or according to their cell dimensions. The strain BCCUSP09 was not included in any of the clusters and it showed low values of similarity among the others.

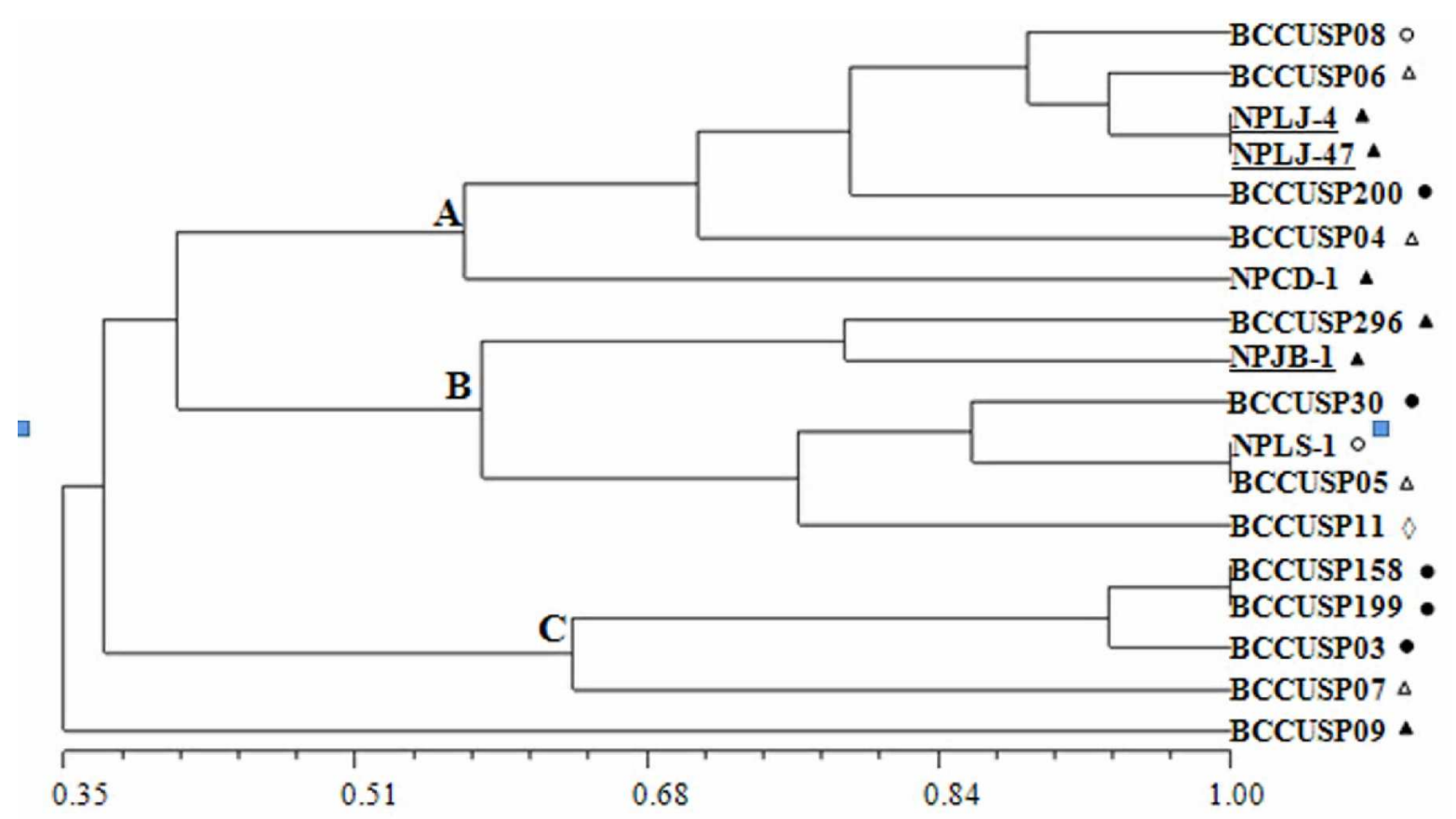

Figure 3 - Clustering dendrogram of Microcystis spp. strains by UPGMA analysis of similarity matrix data using 18 OTUs (operational units taxonomic), and Jaccard's coefficient. The numerical scale indicates the level of similarity at which clusters are formed, according to the Jaccard's coefficient. The underlined codes are strains which produces microcystins. $\mathrm{A}=0.57, \mathrm{~B}=0.58$ and $\mathrm{C}=0.63 . \mathrm{r}=0.880$ (cophenetic correlation). M. aeruginosa $\mathbf{\Lambda}, M$. panniformis $\bullet$, M. protocystis $\Delta$, M. wesenbergii $\diamond$, Microcystis sp. 0 .

\section{DISCUSSION}

In the Brazilian Microcystis populations a single product was amplified for the phycocyanin operon with $\sim 700 \mathrm{bp}$. The amplifications of this fragment in the strains from Australia, Canada and Japan provided products varying from 500 to $640 \mathrm{bp}$ (Neilan et al., 1995; Neilan, 1996; Bolch et al., 1996) showing, thus, the genetic polymorphism among the Brazilian strains and those from other localities.

According to Bolch et al. (1996), some cyanobacteria strains have two or three operons cpc distinctly expressed under differentiated growing conditions. Because of IGS size variation, two different amplified products could be expected in the species with more than one operon. Nevertheless, lack of additional fragments, as was the case with the results here presented, suggested each operon to be unique to the genus.

The fifteen genotypes obtained in the 18 analyzed strains showed a high degree of polymorphism among the Brazilian Microcystis populations (Fig. 2 , Table 1). Such variability could justify the presence of several morphotypes largely found in the nature. According to Kato et al. (1991), 
Japanese strains of $M$. aeruginosa were highly differentiated in their morphology and allozymes composition. These authors suggested this species was constituted by more than one taxonomic entity.

The ample genetic variability of Brazilian Microcystis populations as established in this study was also demonstrated for other cyanobacteria genus (Neilan et al., 1995; Barker et. al., 2000; Manen and Falquet, 2002; Janson and Granéli, 2002, Bittencourt-Oliveira and Moura, 2007).

The restriction enzymes here utilized provided several polymorphic fragments; in the digestion, however, some of them were more efficient than the others. When used by Neilan et al. (1995) and Bolch et al. (1996), the enzymes Sau 3AI, Rsa I and Hae III equally produced polymorphisms among the strains of $M$. aeruginosa. Hha I and Msp I revealed several profiles (nine) among the Brazilian populations, which was different from the results of the Australian, Japanese, American and European strains with smaller number of fragments. The variations of the polymorphic profiles from distinct studies indicated the ample genetic variability of Microcystis at a world wide scale.

The three generated clusters were not grouped according to their geographical origin, water body, morphospecies, cell dimensions, or toxicity. Microcystins were produced via a multifunctional enzyme (Dittmann et al., 1997), a peptide synthetase, and did not relate to the genes which encoded for c- phycocyanin ( $c p c \mathrm{~A}$ and $c p c \mathrm{~B})$.

The Brazilian Microcystis strains exhibited a huge genetic diversity. Morphologically similar strains like BCCUSP04 and BCCUSP05 (M. protocystis), but with very different genotypes, were included into different clusters. On the other hand, the BCCUSP199, BCCUSP03 and BCCUSP158 ( $M$. panniformis) strains, with almost $100 \%$ of similarity, were reunited in the same cluster (Fig.3).

Early studies of the morphological and genetic variation of Microcystis morphospecies have shown some correlation between the morphological and genetic groupings. The data presented here indicated that some genotypes or strains displayed consistent morphological characteristics. Some had consistently smaller or larger cell sizes, and some morphospecies appeared to correspond largely with a particular genotype or cluster of closely related genotypes
(Kato et al., 1991, Nishihara et al., 1997; Otsuka et al., 1999; Bittencourt-Oliveira et al., 2001).

Kato et al. (1991) distinguished two morphotypes (Large, L and Small, S) in M. aeruginosa, based on the colonies morphology and, above all, on the cellular diameters. This was a clue indicating that such characteristic was valid when jointly used with genotype data.

According to Neilan et al. (1997, Neilan et al., 1994), some Microcystis strains from different localities displayed the same genotype, indicating that the genus could be cosmopolitan which was based on the sequencing of the gene 16S rRNA. High degrees of similarity among the populations of Japanese, Europeans and Australian $M$. aeruginosa have been found.

The RFLP-PCR technique applied to the $c p c \mathrm{BA}$ IGS revealed itself a useful tool for the study of Microcystis intraspecific genetic polymorphism. It was difficult to envisage a morphological scheme, which could adequately account for the morphological and genetic variability in the genus. The molecular and morphological data presented here reinforced the necessity for a polyphasic approach toward the identification of Microcystis species.

\section{ACKNOWLEDGMENTS}

This study was supported by the CAPES/PPGB/UFRPE, FAPESP (The State of São Paulo Research Foundation- (2000/05157-5, 2003/05773-6) and the Brazilian Council for Research and Development - CNPq (300794/2004$5)$.

\section{RESUMO}

A ocorrência de florações de cianobactérias tóxicas demanda um melhor entendimento da variabilidade genética como um instrumento auxiliar na identificação de espécies colaborando, assim, com o monitoramento de águas destinadas ao abastecimento público. Este estudo objetivou o conhecimento do polimorfismo genético de linhagens tóxicas e não tóxicas de espécies de Microcystis (Cyanobacteria), isoladas de diversas localidades brasileiras, utilizando a técnica molecular RFLP-PCR para o operon que codifica para a c-ficocianina e seu espaçador intergênico 
( $c p c$ BA-IGS). Foram analisadas dezoito linhagens pertencentes as espécies Microcystis aeruginosa, M. panniformis, $M$. protocystis, $M$. wesenbergii e duas outras não identificadas através de dados morfológicos e moleculares. Os resultados moleculares formaram três agrupamentos com baixos valores de similaridade entre si os quais não foram relacionados à origem geográfica, toxicidade ou morfoespécies. As populações brasileiras de Microcystis spp. apresentaram alta diversidade genética quando comparadas com as da Austrália, Japão, Estados Unidos e Europa. Esta ampla diversidade genética pode ser vislumbrada através de diversos perfis eletroforéticos obtidos entre linhagens de uma mesma espécie. Nós encontramos a presença de linhagens tóxicas e não tóxicas em uma mesma espécie, como em $M$. aeruginosa.

\section{REFERENCES}

Azevedo, S. M. F. O.; Evans, W. R.; Carmichael, W. W. and Namikoshi, M. (1994), First report of microcystins from a Brazilian isolate of the cyanobacterium Microcystis aeruginosa. Journal of Applied Phycolology, 6, 261-265.

Barker, G. L. A.; Konopka, A.; Handley, B. A. and Hayes, P. (2000), Genetic variation in Aphanizomenon (Cyanobacteria) colonies from the Baltic Sea and North America. Journal Phycology, 36, 947-950.

Bittencourt-Oliveira, M. C. (2000), Development of Microcystis aeruginosa (Kützing) Kützing (Cyanophyceae/Cyanobacteria) under cultivation and its taxonomic implications. Algological Studies, 99, 27-37.

Bittencourt-Oliveira, M. C.; Oliveira, M. C. and Bolch, C. J. S. (2001), Genetic variability of some Brazilian strains of Microcystis aeruginosa complex (Cyanophyceae/ Cyanobacteria) using the nucleotide sequence analysis of the intergenic spacer and flanking regions from $c p c \mathrm{BA}-$ phycocyanin operon. Journal Phycology, 37, 810-818.

Bittencourt-Oliveira, M. C.; Kujbida, P.; Cardozo, K. H. M.; Carvalho, V. M.; Moura, A. N., Colepicolo, P. and Pinto, E. (2005), A novel rhythm of microcystin biosynthesis is described in the cyanobacterium Microcystis panniformis Komárek et al. Biochemical and Biophysical Research Communication, 326, 687 694.
Bittencourt-Oliveira, M. C. and Moura, A. N. (2007), Genetic Diversity in Geitlerinema amphibium and $G$. unigranulatum (Cyanobacteria) by HIP1 DNA Fingerprinting. Brazilian Archives of Biology and Technology, prelo.

Bittencourt-Oliveira, M. C.; Moura, A. N., GouvêaBarros, S. and Pinto, E. (2007), HIP1 DNA fingerprinting in Microcystis panniformis (Chroococcales, Cyanobacteria). Phycologia, 46, 3-9.

Bolch, C. J. S.; Orr, P. T.; Jones, G. J. and Blackburn, S. I. (1999), Genetic, morphological, and toxicological variation among globally distributed strains of Nodularia (Cyanobacteria). Journal Phycology, 35, 339-55.

Carmichael, W. W. ; Azevedo, S. M. F. O.; AN, J. S.; Molica, R. J. R.; Jochimsen, E. M.; Lau, S., Rinehart, K. L.; Shaw, G. R. and Eaglesham, G. K. (2001), Human fatalities from cyanobacteria: chemical and biological evidence for cyanotoxins. Environmental Health Perspectives. Environmental Health Perspectives, 109, 663-668.

Codd, G. A.; Bell, S. G.; Kaya, K.; Ward, C. J.; Beattie, K. A. and Metcalf, J. S. (1999), Cyanobacterial toxins, exposure routes and human health. European Journal of Phycology, 34, 405-15.

Dittmann, E.; Neilan, B.; Erhard, M.; Von Döhren, H. and Börner, T. (1997), Insertional mutagenesis of a peptide sinthetase gene which is responsible for hepatotoxin production in the cyanobacterium Microcystis PCC7806. Molecular Microbiology, 26, 779-787.

Janson, S. and Granéli, E. (2002), Phylogenetic analyses of nitrogen-fixing cyanobacteria from Baltic Sea reveal sequence anomalies in the phycocyanin operon. International Journal Systematique Evolution Microbiology, 52, 1397-1404.

Jochimsen, E. M.; Carmichael, W. W.; Na, J.; Cardo, D. M.; Cookson S.T.; Holmes, C. E. M.; Antunes, B. C.; Melo-Filho, D. A.; Lyra, T. M.; Barreto, V. S. T.; Azevedo, S. M. F. O. and Jarvis, W. R. (1998), Liver failure and death after exposure to microcystins at a hemodialysis center in Brazil. New England Journal Medical, 338, 873-78.

Kato, T.; Watanabe, M. F. and Watanabe, M. (1991), Allozyme divergence in Microcystis (Cyanophyceae) and its taxonomic inference. Algological Studies, 64, 129-40.

Komárek, J. and Anagnostidis, K. (1999), Cyanoprocaryota: Chroococcales Süsswasserflora von Mitteleuropa, 19/1, 548p., Gustav Fischer Verlag, Stuttgart.

Komárek, J.; Azevedo, S. M. F. O.; Domingos, P., Komárková, J. and Tichý, M. (2001), Background of the Caruaru tragedy: a case taxonomic study of toxic cyanobacteria Algological Studies, 103, 9-29. 
Komárek, J. and Komarková, J. (2002), Review of European Microcystis-morphospecies (Cyanoprokariotes) from nature. Czech Phycology, 2, 2-14.

Komárek, J.; Komarková-Legnerová, J.; Sant' Anna, C. L.; Azevedo, M. T. P. and Senna P. A. C. (2002), Two common Microcystis species (Chroococcales, Cyanobacteria) from tropical America, including $M$. panniformis sp. nov. Cryptogamie Algologie, 23,159177.

Manen, J. F. and Falquet, J. (2002), The $c p c \mathrm{~B}-c p c \mathrm{~A}$ locus as a tool for the genetic characterization of the genus Arthrospira (Cyanobacteria): evidence for horizontal transfer. International Journal Systematique Evolution Microbiology, 52, 861-867.

Neilan, B. A.; Hawkins, P. R.; Cox, P. T. and Goodman, A.E. (1994), Towards a molecular taxonomy for the bloom-forming cyanobacteria. Australian Journal Marine and Freshwater Research, 45, 869-873.

Neilan, B.A.; Jacobs, D.; Goodman, A.E.; Cox, P.T. and Hawkins, P. (1995), Genetic diversity and phylogeny of toxic cyanobacteria determined by DNA polymorphism within the phycocyanin locus. Applied Environmental Microbiology, 61, 3875-83.

Neilan, B. A. (1996), Detection and identification of cyanobacteria associated with toxic blooms: DNA amplifications protocols. Phycologia, 35, 147-155.

Neilan, B.A.; Stuart, J.L.; Goodman, A.E.; Cox, P.T. and Hawkins, P. R. (1997), Specific amplification and restriction polymorphisms of the cyanobacterial rRNA operon spacer region. Systematique Applied Microbiology, 20, 612-621.

Nishihara, H.; Miwa, H.; Watanabe, M.; Nagashima, M.; Yagi, O. and Takamura, Y. (1997), Random Amplified Polymorphic (RAPD) analyses for discriminating genotypes of Microcystis cyanobacteria. Bioscience Biotechnology Biochemical, 61, 1067-1072.

Odebrecht, C.; Azevedo, S.M.F.O.; Garcia, V.M. T.; Huszar, V.; Magalhães, V.F.; Menezes, M.; Proença, L. A. O.; Rorig, L. R.; Tenenbaum, D. R.; Villac, M.C. and Yunes, J. S. (2002), Floraciones de microalgas nocivas en Brasil: estado del arte $y$ projectos en curso. -In: Floraciones algales nocivas en el Cono Sur Americano, eds. Sar, E.A., Ferrario,
M. E., Reguera, B., Instituto Español de Oceanografia, pp. 219-233

Otsuka, S.; Suda, S.; Li, R.; Watanabe, M.; Oyaizu, H.; Matsumoto, S. and Watanabe, M. M. (1999), Phylogenetic relationships between toxic and nontoxic strains of the genus Microcystis based on 16S to $23 \mathrm{~S}$ internal transcribed spacer sequence. FEMS Microbiology Letters, 172, 15-21.

Otsuka, S.; Suda, S.; Li, R.; Matsumoto, S. and Watanabe, M. M. (2000), Morphological variability of colonies of Microcystis morphospecies in culture. Journal Genetic Applied Microbiology, 46, 39-50.

Rippka, R.; Deruelles, J.; Waterbury, J.B.; Herdman, M. and Stanier, R.Y. (1979), Generic assignments, strain histories and properties of pure cultures of cyanobacteria. Journal Genetic Microbiology, 111, 161.

Skulberg, O. M.; Underdal, B. and Utkilen, H. (1994), Toxic water bloom with cyanophytes in Norway current knowledge. Algological Studies, 75, 279-289.

Sneath, P. H. A. and Sokal, R. R. (1973), Numerical taxonomy: the principles and practice of numerical classification. W.H. Freeman, San Francisco.

Soares, R. A.; Magalhães, V. F. and Azevedo, S. M. F. O. (2004), Accumulation and depuration of microcystins (cyanobacteria hepatotoxins) in Tilapia rendalli (Cichlidae) under laboratory conditions. Aquatic Toxicology, 70, 1-10.

Vasconcelos, V. M.; Sivonen, K.; Evans, W. R.; Carmichael, W. W. and Namikoshi, M. (1996), Hepatotoxic microcystin diversity in cyanobacterial blooms collected in portuguese freshwaters. Water Research, 30, 2377-2384.

Watanabe, M., (1996), Isolation, cultivation, and classification of bloom-forming. In- Microcystis in Japan ,ed. Watanabe, M.F.; Harada, K.; Carmichael, W.W. and Fujiki, H. Toxic Microcystis. CRC Press, Boca Raton, pp. 13-34.
Received: June 14, 2006; Revised: April 02, 2007; Accepted: August 18, 2008. 